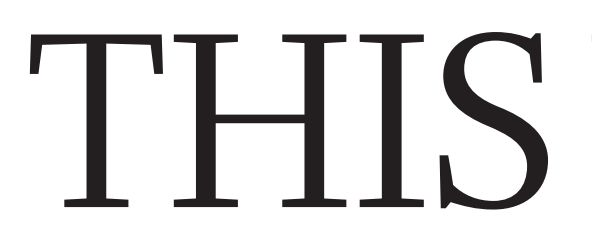

EDITORIALS
TABLET The international weekly journal of science on the iPad p.154
WORLD VIEW Everything science tells us about obesity is wrong $\mathbf{p} .155$

\title{
Words are not enough
}

\section{The political inertia that characterizes the world's response to global warming cannot continue. Politicians and policy-makers must follow the climate's lead - and change.}

$\mathrm{T}$ The past week saw a number of pronouncements on the subject of climate change. Not surprising given that, in Doha, the United Nations was wrapping up the latest round of its annual political negotiations on a global agreement to regulate greenhouse-gas emissions. But the words, and the bundle of small practical actions, that emerged from the meeting had a familiar ring.

"There has been, yet again, a very big mismatch between the scale and urgency of action required to effectively manage the huge risks of climate change, and the political will and ambition that has been displayed," said Nicholas Stern, chair of the Grantham Research Institute on Climate Change and the Environment at the London School of Economics.

"This package offers improved continuity from existing carbon markets to the new markets of the future. But it still won't inspire action at the scale commensurate with the Copenhagen objective of limiting warming to $2^{\circ} \mathrm{C}$," said Dirk Forrister, president of the International Emissions Trading Association.

Both statements tell you that the Doha talks followed the recent trend: warm political words but little sign of serious action. There was some minor progress on secondary issues, just enough to keep the show on the road, but little to address the core problem of soaring emissions.

There were some familiar problems as well. Here's Oleg Shamanov, Russian negotiator at Doha, grumbling at the way his objection to the final Doha text was overruled: "It has to be clearly stated that this is an outrageous violation and absolutely unacceptable conduct of business. The way those decisions were adopted extremely seriously undermines the legitimacy of the regime." And Christiana Figueres, executive secretary of the UN's Framework Convention on Climate Change: "What we understand is that what Russia wants and needs is actually in those texts so my recommendation to our good Russian colleague is to take the time to read these texts."

Once again, the climate talks dragged on into the small hours, way past their scheduled finish time, and descended into acrimony even with so little of substance on the negotiating table. A late and messy end is becoming as much a pre-Christmas tradition as the trees erected in the airports that the delegates pass through on their way home. "In the 16 years we have been coming to these conferences, there has been no global warming at all." That statement came from the British climate sceptic Christopher Monckton, who impersonated a delegate from Myanmar to address the conference floor, and did at least offer some light relief. "Can we have your conference pass back, please?" was pretty much the UN response. "Oh, and don't come back."

Bona fide attendees at Doha together produced a plan and timetable of sorts towards establishing a new agreement in 2015. In the meantime, a weakened Kyoto Protocol was extended to 2020, minus the signatures of Russia, Canada and Japan. Talks on how the rich world

will finance efforts to cut emissions and adapt to changed weather patterns in the poor world ran into the desert sand and will be taken up again at the end of 2013 in Warsaw.

Away from Doha, here is another statement on climate change: average global temperature will rise by $0.7-1.5^{\circ} \mathrm{C}$ between 1990 and 2030 ,

"The global atmosphere, the planet itself, has shifted while the politics has stood still." \section{stood still. "} researchers David Frame and Dáithí Stone analyse that original prediction - and its success (D. J. Frame and D. A. Stone Nature Clim. Change http://doi.org/jx6; 2012). "It seems highly likely that even in 1990 we understood the climate system well enough to make credible statements about how its aggregate properties would change on timescales out to a couple of decades," they write.

And, from the same paper, here's a line on climate that deserves to roll around the world. "The scientific community has now been working on the climate change topic for a period comparable to the prediction and the timescales over which the climate is expected to respond." The global atmosphere, the planet itself, has shifted while the politics has stood still. What more is there to say?

\section{Life on land}

\section{Evidence for the first land life is controversial, but the fossil record has a tendency to surprise.}

W

hen did life first appear on land? The answer to this question - one of the most fundamental in science rather depends on the values you choose for 'life' and 'land'.

There is certainly evidence for freshwater life - pond life, essentially - a billion years ago or so (P. K. Strother et al. Nature 473, $505-509 ; 2011)$. Apart from that, the evidence is indirect and inferred from signs of weathering of non-marine rocks and the presence of apparent palaeosols - sediments indicative of fossilized soil that, by definition, were exposed to the air. Actual fossils that might be signs of land life in the Precambrian eon (before 542 million years ago) are exceedingly rare - or, some say, mythical.

It is a highly controversial subject, and one scientist who didn't shy away from controversy was the late palaeobotanist Jane Gray. Starting in the 1950s, Gray argued, often vociferously, for the presence of 